\title{
Analysis on the Problems and Reasons in the Guidance of Career Planning in Colleges and Universities
}

\author{
Zhang Rui ${ }^{1}$ a \\ ${ }^{1}$ College of Computer Science,Neijiang Normal University Neijiang, Sichuan 641112) \\ a ruizh-80@163.com
}

Keywords: College Career Planning Guidance; Occupation Career Planning Curriculum System; Problems; Analysis of Related Reasons

\begin{abstract}
The university is the buffer stage of a person entering into the society and future occupation career, and career planning at this stage is the key to the success of students in employment or to establish their own career. However, with the increasing number of higher education enrollment in China, the university has changed from elite education to civilian education, and the employment depression of college students has been gradually aggravated, obviously, it is imminent to establish and improve the college students' occupation planning system. However, the poor teachers' professional level, the imperfect occupation career planning curriculum system and other kinds of problems are existed in China's current college occupation career planning system, and these problems greatly affect the efficiency of the system. To solve these problems, school need to correct their concept of career planning, improve the professional level of teachers, and establish a personalized occupation career planning guidance system.
\end{abstract}

\section{Introduction}

Career planning, as the name suggests, which means the dynamic process for the career planning professor implements a comprehensive analysis and design towards the students' occupation type, height of career orientation, career character tendency, and career goals according to their character and career orientation .It means a lot to the college students before they enter into the society, but there are some serious problems existed in career planning courses that need to be urgent solved.

\section{The Problems of Our Country's College Career Planning Guidance}

Neglected College Career Guidance. Although colleges and universities have set the occupation career planning guidance courses, but the position towards the courses is not accurate, and the attention is not enough. ${ }^{[1]}$ On the one hand, many colleges and universities just treat the occupation career planning guidance as an ordinary course to get credits, On the other hand, if you want to carry out the occupation career planning guidance, you must get the support of the relevant hardware and finance, but according to table 1 shows, the invested capital of occupation career planning of A university is only less than $1 \%$ of the school expenses, which resulted in the occupation career planning guidance facing poor hardware, lack of funds, etc.

Table 1.annual expenditure of A university

Ttem of expenditure Amount (ten thousand Yuan) $\quad$ Percentage (\%)




$\begin{array}{lcc}\text { Teaching equipment purchase } & 860 & 10.7 \\ \text { Water and electricity cost } & 600 & 7.5 \\ \text { Books purchase } & 830 & 10.3 \\ \text { Greening maintenance } & 600 & 7.5 \\ \text { Teaching equipment maintenance } & 64 & \\ \text { Career planning guidance maintenance financial support } & 56 & 0.8 \\ \text { Total amount: } 8000 & & \end{array}$

Poor Professional Level of Career Planning Guidance Teacher. There are a lot of problems existed in setting up the teaching body of the occupation career planning guidance in most college. Career planning guidance is mainly managed by college counselors, which is the main problem.college counselors are responsible for the daily management of college students, basically, their knowledge is nothing to do with the occupation career planning guidance. ${ }^{[2]}$

Imperfect Career Planning Guidance System. At present, although most of China's colleges and universities carry out career planning guidance courses, the traditional teaching methods is still adopted in teaching---the passive mode, namely, the teachers speak, and the students listen. The emphasis of this kind of teaching is the elaboration of the theory of employment, but ignores the current employment practice, so the actual value is very limited.

The career planning guidance of colleges and universities in our country mainly take the traditional classroom teaching mode----teacher faces all the students to explain relevant knowledge, however, each student has his own unique personality characteristics, career orientation, specialties and hobbies., which means this mode could not establish a suitable personal career plan for each student, and the actual results are not satisfactory. ${ }^{[3]}$

\section{The Analysis of the Reasons Towards the Problems of Career Planning Guidance}

The Career Planning Guidance is Equivalent to the Employment Guidance. Their concept is different: the main content of the occupation career planning guidance is to help people determine their occupation planning and tendency, locate his occupation type and determine his occupation target and height through the scientific method. But as for the employment guidance, whose main content is to explain China's current employment policy to university graduates to help them prepare employment materials, and improve their interviewing skills. ${ }^{[4]}$ However, many universities in our country think that the occupation career planning guidance is equal to the employment guidance, which is a wrong concept. In the influence of the wrong idea, it is difficult for students to form a system, comprehensive career planning, and leading the career guidance curriculum to an optional position and its practical significance is unlikely.

Ignore the Role of Career Planning Guidance Played in College Students' Career. College is a base of training qualified personnel for the modernizations. During the college students' learning system, not only learning the professional knowledge, most of all, they need to get the occupation guidance to improve their occupation skills, and expand their occupation horizons. However, for a long time, many colleges and universities only pay attention to teaching and research work, ignore the aim of cultivating talents in colleges and universities, and ignore the role 
of career education played in personnel training, only treat the career education as a routine work, and failed to enhance it to the school strategic level, such as some schools think that carry out vocational career education is to hold a job lecture, or a graduate supply and demand fair and to recommend the employment of graduates; some schools still think that career education doesn't means too much to school itself, it's a social thing.

Neglect the Role of Occupation Career Planning Education Played in Teaching Management. The occupation career planning education can help students to establish a regular professional view, and let them know the insufficiency of their knowledge and ability in employment later on, so as to acquire related knowledge better to develop their own specific goals; it can not only improve the overall style of study, but also improve the management of university teaching. However, the universities do not attach importance to the role occupation career planning education played in teaching, which makes the students have no goals in the process of learning, lack of initiative and enthusiasm, with that ,it makes the teaching mission of the school fail to achieve the expectations, and increase the difficulty of teaching management.

\section{Advices of Improving the Guidance of Career Planning in Colleges and Universities}

Colleges and Universities Should Establish a Correct Concept of Career Guidance. Our universities do not pay much attention to occupation career planning guidance and they also do not establish a correct concept. To solve this problem, the universities should play it on a strategic height, correct attitude, increase the investment of the hardware and software of occupation career planning guidance. They should establish the occupation career planning guidance system that is suitable for each student, and set up an occupation career planning guidance center, which is mainly responsible for the full occupation career planning guidance of students from their entry into the school. School should not only conduct the test of occupation tendency to the students, but also establish an occupation career planning guidance curriculum system accordingly, improve every student's occupation ability comprehensively, and help each one to establish a correct concept of occupation.

Improve the Professional Level of Teachers in Career Planning. Our teaching body of occupation career planning guidance of university mainly consists of college counselors or ideological and political teachers that are lack of professional knowledge and ability of career planning. To improve this situation, colleges and universities should strengthen the teacher training of occupation career planning guidance, and conduct the examination and assessment after the training, then arrange qualified teachers to participate in training and occupation planning examination, increase the number of teachers held the occupation planner certificate proportion so as to improve the professional level of teachers' occupation planning guidance and teaching quality.

Establish a Sound Career Planning Guidance System. It is important to found an occupation career planning guidance system to help students to build up their own occupation goals, types and specific plans, thus these following points should be included in this system : carry out the occupation skill training to improve the students' occupation skill level; conduct the occupation 
personality test to each student with the professional occupation personality test system; carry out the occupation simulation training regularly to help them to identify their location.

Develop a Personalized Career Planning Guidance. At present, the college career planning guidance curriculum guide all students with no difference, which is unrewarding because of the differences of students' personal characteristics. To change this situation, school should develop a guidance that is suitable for everyone according to each student's personality, career orientation, professional ability and hobbies. Owing to taking account of both of the students' personal characteristics and basic theory of career planning, such a personalized guidance can play a greater role. ${ }^{[5]}$

\section{Summary}

In short, the emphasis towards the career planning of the school is the necessary guarantee to promote the education of occupation planning. Colleges need to strengthen the management and service of the work of the occupation career planning education .Promote this work sturdy and guide the students to design their own occupation career independently through meticulous organization, reasonable arrangement, and perfect team and the supply of protection. In addition, the school also need to strengthen the communication and contact with the society and enterprises, with this, school could guide students to participate in the social practice of their relevant major, and arrange students to work as an internship to help them to get a clear perception towards the status of their major and the relevant job they may engage in the future.

\section{References}

[1] Xiaoyun Li,Shiwei Lin. The Effective Combination of College Students' Occupation Career Planning and Ideological and Political Education[A]. International Informatization and Engineering Associations 、Atlantis Press.Proceedings of 2nd International Conference on Science and Social Research(ICSSR 2013)[C].International Informatization and Engineering Associations、Atlantis Press:,2013:5.

[2] Lichun Niu,Xiang Lv. Research on occupation career planning of the college PE teacher[A]. Information Engineering Research Institute, USA.Proceedings of the 2014 Asia-Pacific Congress on Sports Technology and Engineering(STE 2014)[C].Information Engineering Research Institute, USA:,2014:6.

[3] Yuan Song. Research of College Students' Career Planning and Employment[A]. International Informatization and Engineering Associations 、 Atlantis Press.Proceedings of 2015 International Conference on Management Science,Education Technology,Arts,Social Science and Economics (MSETASSE 2015)[C].International Informatization and Engineering Associations、Atlantis Press:,2015:5.

[4] Bingquan Yin,Baojing Ni,Yali Hou. Questions and Strategies in Terms of Higher Vocational College Career Guidance[A]. Information Engineering Research Institute, USA.Proceedings of 2015 3rd International Conference on Social Science and Education(ICSSE 2015 V74)[C].Information Engineering Research Institute, USA:,2015:4.

[5] Chengli Chen. Role Definition and Practice of Colleges and Universities in Boosting the Occupation Planning of College Students[A]. Information Engineering Research Institute, USA.Proceedings of 2014 2nd International Conference on Social Science and Health(ICSSH 2014 V55)[C].Information Engineering Research Institute, USA:,2014:5. 